sition of Mendelian inheritance. Phil. Trans. R. Soc. Edin. 52, 399-433.

Hallgrimsson B. and Hall B. K. (ed.) 2005 Variation: a central concept in biology. Elsevier Academic Press, Burlington.

Kohler R. 1994 Lords of the fly: Drosophila genetics and the experimental life. Chicago University Press, Chicago.
Rose M. R. 2000 Darwin's spectre: evolutionary biology in the modern world. Princeton University Press, Princeton.

Sturtevant A. H. 2001 A history of genetics. Cold Spring Harbor Laboratory Press, Cold Spring Harbor, New York.

Wagner G. P. (ed.) 2001 The character concept in evolutionary biology. Academic Press, San Diego.

Received 26 November 2008; accepted 26 November 2008

Published on the Web: 1 December 2008

\title{
Erratum
}

\section{Haldane and the first estimates of the human mutation rate}

(A commentary on J.B.S. Haldane 1935 J. Genet. 31, 317-326; reprinted in volume 83, 235-244 as a J. Genet. classic)

Michael W. Nachman

J. Genet. 83, 231-233

Page 1, right column, para 1, line 6 from bottom, 'three times' should read 'one third'. 